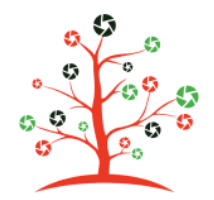

ISSN: $2455-460 X$

\author{
REGULARARTICLE
}

\title{
STUDIES ON EFFECT OF INDUCED MUTAGENESIS ON FINGER MILLET (ELEUSINE CORACANA (L.) GAERTN.) VAR-CO 13 IN M1 GENERATION
}

\author{
K. AVIYA*, L. MULLAINATHAN
}

Department of Botany, Annamalai University, Annamalai Nagar 608002, Tamil Nadu, India

\begin{abstract}
The present study was carried out to induce chemical mutagens in Finger millet (Eleusine coracana (L.) Gaertn.). The seed were subjected to different treatment level of EMS and DES. The parameters like Plant height(cm), Number of leaves per plant, Leaf length (cm/plant), Number of finger per plant, Finger length $(\mathrm{cm} /$ plant), Days to first bloom, Yield per plant (g) and 1000 grains weight (g)were observed in $\mathrm{M}_{1}$ generation. And the result revealed that, all the parameters except days to first blooming show a dose dependent decrease in both treatments. The LD- ${ }_{50}$ value was found in 30 mmol of EMS and $40 \mathrm{mmol}$ of DES.
\end{abstract}

Keywords: EMS, DES, LD5o value, Finger millet, $\mathrm{M}_{1}$ germination

\section{INTRODUCTION}

Finger millet (Eleusine coracana (L.) Gaertn.) Popularly known as 'Ragi' belongs to family 'Poaceae. Finger millet is having highly nutritious constituents and also medicinal properties [1]. There are reports that clearly describe the use of finger millet in diabetic patients [2]. Recent years the production of ragi is found to be highly reduced due to soil quality degradation and other environmental stresses [3]. There is urgent need to develop elite verities of finger millet which can withstand harsh environmental conditions and defective soil problems. Apart from environmental issues, diseases are other major threat in finger millet cultivation. Since many years, there are some researches related to the development of prime varieties of plants by breeding and even through modern technologies [4].

Mutation is quite often used in modern plant breeding [5]. In the present investigation, an attempt has been made to study the effect of induced mutagenesis on Finger millet (Eleusine coracana (L.) Gaertn.) Var-CO 13 in M1 generation.

\section{MATERIALS AND METHODS}

\section{Mutagens employed}

Chemical mutagens namely, Ethyl Methane Sulphonate and Diethyl sulfate were used at various concentrations to induce mutagenesis.

\section{Mutagenic treatments}

Ethyl methane Sulphonate (EMS) $\left(\mathrm{CH}_{3} \mathrm{SO}_{2} \mathrm{OC}_{2} \mathrm{H}_{5}\right)$, an alkylating agent having molecular weight 124.16 was used in the present study. For the treatment of EMS, the seeds were pre-soaked in distilled water for $6 \mathrm{~h}$ in order to make them relatively more sensitive to mutagenic action. Pre soaked seeds were treated with different concentrations of EMS (10, 20, 30, 40 and $50 \mathrm{mmol}$ ) for 4 hours with repeated stirring. After the chemical treatment, the treated seeds were washed thoroughly in running tap water to remove the residues of the chemicals. Healthy, well-matured and untreated seeds were used as control. Diethyl sulphate (DES) treatment was done as described previously [6].

Seeds of Finger millet were subjected to different treatment levels $(20,30,40,50$ and $60 \mathrm{mmol})$ of Diethyl sulphate for induced mutagenesis. Before treatment, seeds were pre-soaked in distilled water for $12 \mathrm{~h}$ at room temperature. Later these seeds were dried on filter paper. All seeds were uniformly exposed to Diethyl sulphate solution by stirring with a glass rod. After treatment seeds were rinsed thoroughly with distilled water.

The treated seeds were sown in seed beds and watered at least once a day. After 25-30 d the seedlings were transplanted to experimental field in Completely Randomized Block Designs(CRBD) with three replicates to raise $M_{1}$ population. The $M_{1}$ generation (produced directly from mutagen treated seeds) was grown in the field.

\section{RESULTS}

\section{Plant height (cm/plant)}

Both the mutagenic treatments had an inhibitory effects of plant height when compared to control. The highest

\footnotetext{
Received 21 March 2018; Accepted 19 April 2018

*Corresponding Author

K. Aviya

Department of Botany, Annamalai University, Annamalai Nagar 608002, Tamil Nadu, India

Email: aviyakmsc@gmail.com

( $T$ This article is open access and licensed under the terms of the Creative Commons Attribution License (http://creativecommons.org/licenses/by/4.o/) which permits unrestricted, use, distribution and reproduction in any medium, or format for any purpose, even commercially provided the work is properly cited. Attribution - You must give appropriate credit, provide a link to the license, and indicate if changes were made.
} 
reduction in plant height was noted at $60 \mathrm{mmol}$ of DES (48.21), followed by $50 \mathrm{mmol}$ of EMS (52.65).

\section{Number of leaves per plant}

A gradual reduction of mean performance was noticed in leaves per plant for all the mutagenic concentration when compared to control. Among them, the highest reduction was observed at $60 \mathrm{mmol}$ of DES (16.30) followed by $50 \mathrm{mmol}$ of EMS (17.10) than control plants (25.55) and other treatments.

\section{Leaf length (cm/plant)}

Both the mutagenic treatment significantly effects the leaf length when compared to control. Among the different concentration, the highest reduction of mean values was observed in $50 \mathrm{mmol}$ of EMS (37.54) followed by $60 \mathrm{mmol}$ in DES (35.45).

\section{Number of fingers per plant}

The mean performance of total number of finger per plant were decreased gradually in both treatments when compared to control. The highest reduction in number of fingers per plant was recorded at $50 \mathrm{mmol}$ of EMS (3.95) and $60 \mathrm{mmol}$ in DES (3.55) than the control.

\section{Finger length (cm/plant)}

There was slight reduction in finger length was recorded at all the mutagenic treatments. However, among the various mutagenic treatments the highest reduction in finger length was observed in $50 \mathrm{mmol}$ of EMS (6.12) and 60 mmol in DES (6.06).

\section{Days to first bloom}

The days to first bloom was gradually increasing with increasing concentration when compared to control. Among them, $50 \mathrm{mmol}$ of EMS was taken more days for first bloom; whereas, in DES $60 \mathrm{mmol}$ was taken more days to first bloom when compared to control.

\section{Yield per plant (g)}

A significant effect was observed on yield per plant in both mutagenic treatments. Among them, the highest reduction was observed at $50 \mathrm{mmol}$ of EMS (6.37) followed by 60 mmol of DES (6.10) when compared to control and other concentrations.

\section{0 grains weight (g)}

1000-gram weight is considered as an important character, because it directly influences the yield per plant. Both the mutagenic treatments were significantly reducing the 1000-gram weight when compared to control. The highest reduction of grains weight was recorded at $50 \mathrm{mmol}$ (1.95) of EMS and 6o mmol (1.80) in DES.

\section{DISCUSSION}

In this study, the $M_{1}$ generation indicated highly significant reduction for all the traits such as Plant height $(\mathrm{cm})$, Number of leaves per plant, Leaf length (cm/plant), Number of finger per plant, Finger length (cm/plant), Days to first bloom, Yield per plant $(\mathrm{g})$ and 1000 grain weight $(\mathrm{g})$ studied. This might be due to the first generation $\left(M_{1}\right)$ had growth inhibition $[7,8]$. Our results are in agreement with previous reports [9-11]. The effect of sodium azide on tomato revealed that these decreased traits were concentration dependent [12]. Similar results were obtained by Sheeba et al. [13] when gamma rays and EMS were used to treat Sesamum. Peiris [14] reported that seedling emergence, seedling survival at $14 \mathrm{~d}$ and at maturity decreased in treated tomato plants. Flowering and maturity were also delayed in treated plants.

\section{CONCLUSION}

In this study, Plant height (cm), Number of leaves per plant, Leaf length (cm/plant), Number of finger per plant, Finger length (cm/plant), Days to first bloom, Yield per plant $(\mathrm{g})$ and 1000 grains weight $(\mathrm{g})$ were studied under the field condition in $\mathrm{M}_{1}$ generation. Mean performance of different quantitative traits were better in control when compared with treated plants. Induced mutagenesis is the best method to enlarge genetic variability within short time. Creation of genetic variability by induced mutagenesis proved best for strengthening crop improvement programmers and represents a more efficient source of genetic variability than the gene pool protects by nature.

Table 5: Effect of chemical mutagens on plant height $(\mathrm{cm})$, number of leaves per plant, leaf length (cm/plant), number of finger per plant, Finger length $(\mathrm{cm} / \mathrm{plant})$, days to first bloom, yield per plant (g), 1000 grains weight $(\mathrm{g})$

\begin{tabular}{|c|c|c|c|c|c|c|c|c|c|}
\hline Mutagens & $\begin{array}{l}\text { Treatments } \\
\text { Conc. }(\mathrm{mM})\end{array}$ & $\begin{array}{l}\text { Plant } \\
\text { height(cm) }\end{array}$ & $\begin{array}{l}\text { Number } \\
\text { of leaves } \\
\text { per plant }\end{array}$ & $\begin{array}{l}\text { Leaf length } \\
(\mathrm{cm} / \text { plant })\end{array}$ & $\begin{array}{l}\text { Number } \\
\text { of fingers } \\
\text { per plant }\end{array}$ & $\begin{array}{l}\text { Finger } \\
\text { length } \\
\text { (cm/plant) }\end{array}$ & $\begin{array}{l}\text { Days to } \\
\text { first } \\
\text { bloom }\end{array}$ & $\begin{array}{l}\text { Yield } \\
\text { per } \\
\text { plant (g) }\end{array}$ & $\begin{array}{l}\text { 100o } \\
\text { grains } \\
\text { weight } \\
\text { (g) }\end{array}$ \\
\hline Control & & $66.87 \pm 1.70$ & $25.55 \pm 1.09$ & $49.33 \pm 1.46$ & $6.25 \pm 0.54$ & $8.54 \pm 0.33$ & $53.90 \pm 0.94$ & $8.25 \pm 0.33$ & $3.01 \pm 0.29$ \\
\hline \multirow[t]{5}{*}{ EMS } & $10 \mathrm{mmol}$ & $63.70 \pm 2.24$ & $24.00 \pm 1.08$ & $47.19 \pm 1.02$ & $5.70 \pm 0.43$ & $7.99 \pm 0.27$ & $55.21 \pm 0.82$ & $8.02 \pm 0.23$ & $2.91 \pm 0.30$ \\
\hline & $20 \mathrm{mmol}$ & $61.70 \pm 1.78$ & $21.70 \pm 0.88$ & $45 \cdot 44 \pm 1.78$ & $4.75 \pm 0.37$ & $7.05 \pm 0.35$ & $57.45 \pm 1.35$ & $7.82 \pm 0.25$ & $2.80 \pm 0.18$ \\
\hline & $30 \mathrm{mmol}$ & $58.31 \pm 2.22$ & $19.95 \pm 0.72$ & $40.83 \pm 1.05$ & $4.45 \pm 0.37$ & $6.96 \pm 0.28$ & $60.18 \pm 1.22$ & $7.14 \pm 0.20$ & $2.55 \pm 0.41$ \\
\hline & $40 \mathrm{mmol}$ & $56.88 \pm 1.41$ & $18.10 \pm 0.74$ & $39.04 \pm 1.16$ & $4.35^{ \pm 0.50}$ & $6.50 \pm 0.25$ & $62.33 \pm 1.54$ & $6.74 \pm 0.47$ & $2.14 \pm 0.19$ \\
\hline & $50 \mathrm{mmol}$ & $52.65 \pm 1.14$ & $17.10 \pm 0.97$ & $37.54 \pm 0.75$ & $3.95 \pm 0.43$ & $6.12 \pm 0.18$ & $66.90 \pm 2.36$ & $6.37 \pm 0.22$ & $1.95 \pm 0.18$ \\
\hline \multirow[t]{5}{*}{ DES } & $20 \mathrm{mmol}$ & $61.16 \pm 1.71$ & $23.20 \pm 0.91$ & $46.62 \pm 0.95$ & $5.10 \pm 0.40$ & $7.51 \pm 0.20$ & $56.21 \pm 1.20$ & $7.88 \pm 0.51$ & $2.86 \pm 0.28$ \\
\hline & $30 \mathrm{mmol}$ & $59.05 \pm 1.81$ & $21.00 \pm 1.03$ & $43.67 \pm 1.00$ & $4.70 \pm 0.37$ & $7.28 \pm 0.30$ & $59.32 \pm 1.40$ & $7.74 \pm 0.25$ & $2.74 \pm 0.40$ \\
\hline & $40 \mathrm{mmol}$ & $55.45 \pm 0.99$ & $19.40 \pm 1.06$ & $41.18 \pm 1.19$ & $4.35 \pm 0.44$ & $7.00 \pm 0.36$ & $62.81 \pm 1.54$ & $7.25 \pm 0.29$ & $2.35 \pm 0.24$ \\
\hline & $50 \mathrm{mmol}$ & $52.10 \pm 1.66$ & $18.30 \pm 1.03$ & $37.95 \pm 1.31$ & $4.05 \pm 0.40$ & $6.54 \pm 0.29$ & $65.42 \pm 1.62$ & $7.07 \pm 0.37$ & $2.04 \pm 0.20$ \\
\hline & $60 \mathrm{mmol}$ & $48.21 \pm 1.77$ & $16.30 \pm 0.81$ & $35.45 \pm 0.88$ & $3.55 \pm 0.35$ & $6.06 \pm 0.42$ & $68.00 \pm 1.81$ & $6.10 \pm 0.29$ & $1.80 \pm 0.17$ \\
\hline
\end{tabular}




\section{ACKNOWLEDGEMENT}

The authors are thankful to the Professor and Head, Department of Botany, Annamalai University for providing necessary facilities.

\section{REFERENCES}

1. Devi PB, Vijayabharathi R, Sathyabama S, Malleshi NG, Priyadarisini VB. Health benefits of finger millet (Eleusine coracana L.) polyphenols and dietary fiber: a review. Journal of Food Science and Technology. 2014;51:1021-40.

2. Hadimani N. A. and Malleshi N. G. Studies on milling, physico-chemical properties, nutrient composition and dietary fibre content of millets. J. Food Sci. Tech., (India), 1993, 30, 17-20.

3. Hittalmani S, Leong S, Devos K. Development of high yielding, disease resistant, drought tolerant Finger millet. Progress report of the Mc knight foundation funded project. 2004:1-82.

4. Witcombe JR, Hollington PA, Howarth CJ, Reader S, Steele KA. Breeding for abiotic stresses for sustainable agriculture. Philosophical Transactions of the Royal Society B: Biological Sciences. 2008 Feb 27;363(1492):703-16.

5. Khan and Tyagi, Induced morphological mutants in soybean [Glycine $\max$ (L.) Merill]. Front. Agric. China, 2010,4: 175-180.

6. Mullainathan, L. and A. Sridevi. Effect of EMS and dES on oleoresin, capsanthin and ascorbic acid contents in chilli. Int. J. Cur. Tr. Res (2012) 1: 110-114.

7. C. O. Ojiewo, S. G. Agong, K. Murakami, A. Tanaka and M. Masuda, Male-sterility induced by gamma ray irradiation of African nightshades (SolanumnigrumL. sp. villosum) seed. J. of Horticultural Science and Biotechnol, 2005, 80:699-704.

8. C. O. Ojiewo, S. G. Agong, K. Murakami, A. Tanaka, Y. Hase and M. Masuda, Biological effect of carbon-ionbeam on mutagenesis and a novel season-dependent floral homeotic mutant in SolanumvillosumMiller. Journal of Horticultural science and Biotech. 2006, 81:559-564.

9. Ambli and mullainathan. L, Induced physical and chemical studies in $\mathrm{m} 1$ generation of pearl millet (Pennisetum typhoides) (burn.) Stapf. var. co (cu)-9 International Journal of Recent Scientific Research, 2014;5:1806-1809.

10. T. Aruldoss and L. Mullainathan, Studies on effect of induced mutagenesis on Capsicum annuum (L). in $\mathrm{M}_{1}$ generation, JCBPS, Sec. B; 2015;5,1:347-352.

11. S. Velu, L. Mullainathan, D. Arulbalachandran and D. Dhanavel, Effect of physical and chemical mutagens in cluster bean (Cyamopsis tetragonoloba (L.) Taub.) in M1 generation. Crop Res., 2007, 34:(1, 2 and 3): 252-254.

12. H. Aliyu H and A. K. Adamu, The effects of diethyl sulphate on some quantitative traits of tomato (Lycopersicon esculentum Mill). Sci. World J., 2007, 2:1-4.

13. Sheeba, S. M. Ibrahim, P. Yogameenakshi and S. Babu, Studies on induced chlorophyll mutation in sesame (Sesamum indicum L.), Madras Agric. J., 2004, 91(1-3): 75-78.

14. R. Peiris, Genetic improvement of tomato variety, Manik, through induced mutations. Annals of the Sri Lanka of Agriculture, 2002, 4:199-205. 